\title{
Bioaccumulation of Heavy Metals in Pelagic and Benthic Fishes of Ogbese River, Ondo State, South-Western Nigeria
}

\author{
Josephine Omowumi Olayinka-Olagunju (D) - Adekunle A. \\ Dosumu (i) - Adetola Mary Olatunji-Ojo
}

Received: 20 August 2020 / Accepted: 2 January 2021 / Published online: 26 January 2021

(C) Crown 2021

\begin{abstract}
The bioaccumulation factors (BAFs) of heavy metal ( $\mathrm{Fe}, \mathrm{Zn}, \mathrm{Pb}, \mathrm{Cd}, \mathrm{Cr}, \mathrm{Cu}, \mathrm{Mn}$, and $\mathrm{As}$ ) concentrations in benthic and pelagic fish organs (muscles, gills, liver, and hearts), and concentrations of heavy metals in water and sediments of Ogbese River, Ondo State, Nigeria were investigated. From the results, the concentrations of heavy metals in the water were within the permissible limits stipulated by the World Health Organization (WHO). However, in the sediments, $\mathrm{Cd}$, $\mathrm{Cr}, \mathrm{Fe}$, and $\mathrm{Mn}$ concentrations were higher than the limits, while $\mathrm{Zn}, \mathrm{As}, \mathrm{Pb}$, and $\mathrm{Cu}$ were within limits. Heavy metals concentrations in the fish organs showed that all fish species were within the permissible limits implying no contamination. More so, the BAFs in all fish organs revealed no probability of accumulation while the geoaccumulation index and contamination factor showed no contamination to moderate
\end{abstract}

J. O. Olayinka-Olagunju • A. M. Olatunji-Ojo

Department of Animal and Environmental Biology, Faculty of Science, Adekunle Ajasin University, Akungba-Akoko, Ondo State PMB 001, Nigeria

J. O. Olayinka-Olagunju

e-mail: josephine.olayinka-olagunju@ aaua.edu.ng

A. M. Olatunji-Ojo

e-mail: adetola.olatunji-ojo@aaua.edu.ng

A. A. Dosumu $(\bowtie)$

Department of Biosciences, School of Science and Technology, Nottingham Trent University, Clifton Lane, Nottingham NG1 1 $8 \mathrm{NS}$, UK

e-mail: adekunle.dosumu@ntu.ac.uk contamination. The potential ecological risk index also showed moderate risk factor indicating that the water and sediments were not extremely polluted for higher organisms but may be toxic for lower ones. The study concludes that constant monitoring and study should be conducted by researchers and the Ministry of Water Resource and that the community should be aware of the danger human pollution can cause to the river.

Keywords Ogbese River - Bioaccumulation factor . Heavy metals $\cdot$ Sediments $\cdot$ Pollution indices $\cdot$ Potential ecological risk

\section{Introduction}

Freshwater and sediment pollutions have not only shown serious ecological threat but also bring about environmental toxicity in many water bodies in developing countries. However, many aquatic environments have been contaminated with pollutants from both natural and anthropogenic activities such as discharge from chemical companies, agricultural activities, solid waste disposal, and flooding (Ali et al. 2016). Ali et al. (2016) and Sánchez-Chardi et al. (2007) argued that human activities pollute the aquatic environment more and such cause increase in heavy metals which may affect water, sediments, and aquatic faunas and floras. Increase in the concentration of heavy metals like zinc ( $\mathrm{Zn})$, copper $(\mathrm{Cu})$, lead $(\mathrm{Pb})$, manganese $(\mathrm{Mn})$, chromium $(\mathrm{Cr})$, and cadmium $(\mathrm{Cd})$ pollutes water and sediments depending on the nature of the activities in the aquatic ecosystem 
(Sharma and Chatterjee 2017; Marshall et al. 2010). Whenever these heavy metals are released into the soil and aquatic ecosystem, they may bioaccumulate and biomagnify in water and soil and may disrupt the organisms' food chain.

Consequently, this disruption may have lethal effects on aquatic organisms (Sharma and Agrawal 2005). According to Vardi and Chenji (2020) supported by Islam et al. (2015) and Authman (2008), fish and sediments are the best bio-indicator recognised for the assessment of heavy metals in the natural aquatic ecosystem. This suggested that fish is associated with much precise benefit in the natural aquatic ecosystem and best used in evaluating the habitat transformation. However, Malik et al. (2015) argued that since fish are situated at the bottom of the aquatic food chain, they may amass heavy metals from the sediment thereby passing it to human through fish consumption and leading to severe health issues. This is because pollutants from solid waste, industrial effluents, and agricultural run-off are quickly deposited into rivers. The health issues may be due to high concentration, persistence, bioaccumulation, and biomagnification of heavy metals in the aquatic environment from the continuous consumption of fish species from contaminated water source over some time (El-Moselhy et al. 2014; Zhao et al. 2012).

Fish consumption is increasing across the globe because of its health and nutritional benefits. The increase in the demand for fish may be attributed to human population increase as well as some underlying health issues among human. Besides being nutritional, it serves as an essential source of protein, vitamins, minerals, and unsaturated fatty acids (low in cholesterols) (Medeiros et al. 2012). Previous studies by the American Heart Association showed that it is important to eat fish at least twice a week to get the quantity of omega-3 fatty acids required for humans per day (El-Moselhy et al. 2014). However, due to some health issues that may be associated with heavy metal contamination in fish, many international monitoring programmes have been created to evaluate the nutritional values of fish before consumption (Marriott et al. 2020; Tacon et al. 2020; Meche et al. 2010).

Mani et al. (2015) argued that $80 \%$ of the pollutants from freshwater are channelled into the marine environment. This argument, therefore, explains the reason for the high level of pollutants in the ocean and low concentrations in many freshwaters. Pollution in water (fresh, brackish, or oceanic) according to Kosygin et al. (2007) may be direct or indirect. Heavy metal contamination in water has been linked to agricultural run-offs from pesticides, herbicides, fertilisers, to industrial effluents (Kaur and Sinha 2019; Singh et al. 2020; Grigoratos et al. 2014; Martin et al. 2015; Sathware et al. 2007); the most severe human pollution sources of water are oil spills, waste disposal, and some hazardous manufacturing activities (Santos et al. 2009; Prasanna et al. 2012). Olivares-Rieumont et al. (2005), for example, argue that heavy metals may be ubiquitous in soils and water and maybe discharged into the water column causing environmental challenges in the community. This discharge, therefore, may affect the aquatic ecosystem, especially in the benthic part, since it is a source of food to both flora and fauna directly or indirectly. Previous studies have shown that high concentrations of heavy metals may cause a significant threat to all forms of aquatic lives as well as human lives (Martin et al. 2015; Islam et al. 2015; Ahmed et al. 2015).

Heavy metal pollutants, for example, may originate naturally in the aquatic environment, but some are released to the aquatic organisms at low concentration (Eneji et al. 2011). It is therefore essential to note that the release of these metals at high concentration may cause serious risk to the aquatic organisms as well as their consumers because they are indigestible (Eneji et al. 2011; Yi et al. 2011). According to Yi et al. (2011) and Solomon et al. (1996), the health risk associated with heavy metal bioaccumulation may be carcinogenic and non-carcinogenic effects. A primary concern with a high concentration of heavy metal in the aquatic ecosystem is that it is very toxic. The toxicity level may affect human health, animals, plants, and aquatic microorganisms (Yadav et al. 2018).

Furthermore, the level of toxicity is associated with concentration absorbed, the organ of metal penetration, and the period of exposure, such as severe or persistent. This becomes necessary as increased toxicity level may lead to a variety of diseases and can lead to severe damage due to oxidative stress induced by free radical formation (Jaishankar et al. 2014). Previous studies, however, showed that consumption of fish with a high concentration of heavy metals cause health implications (Vardi and Chenji 2020; Maurya and Malik 2018; Igharo et al. 2014).

More so, Gao (2001) suggested that fish organs, tissues, and muscles absorb and store up heavy metals from the sediments from water, while other previous studies showed that a high concentration of heavy metal stored in the muscles of fish varies on the river and species. On the 
other hand, sediment takes up heavy metal from the river, thereby causing metal exchange through biological and chemical process amid water, sediments, and fish. However, fish accumulate heavy metals from the river through their respiratory organs (e.g. gill) and assimilation depends on the concentration level in the environment (Maurya and Malik 2018). Mazumder (2008) reveals that, for example, arsenic consumption, either intentional or unintentional, may lead to death in children.

On the other hand, drinking water that has been polluted or exposed to arsenic may cause skin cancer or skin lesions (Jarup 2003). For instance, lead (Pb) a poisonous heavy metal, at a high or low dose, may cause different disruptions in plant physiological processes (Yadav et al. 2018) while other metals, like zinc, copper, and manganese, does not affect the plants because they do not have any significant biological roles (Jaishankar et al. 2014). Exposure to cadmium, for example, at a very minimal concentration may result in kidney injury and may also affect the bones (Maurya and Malik 2016).

Although many studies in Africa have examined the concentrations of heavy metals in different rivers and sediments in Africa, only a few have included the bioaccumulation factors of heavy metal in fishes (Akindele et al., 2020; Eneji et al. 2011; El-Moselhy et al. 2014). More so, in Ondo State, a few studies have been conducted in Ogbese River; many of these studies however only considered the concentrations of heavy metals in the water and sediments (Akinbile and Omoniyi 2018; Olawusi-Peters et al. 2015; Ololade and Ajayi 2009) and no studies have investigated the bioaccumulation of heavy metals in fishes from the River. In a bid to bridge this gap, the present study investigated the bioaccumulation factors (BAFs) of heavy metals in pelagic and benthic fishes (muscles, gills, livers, and heart) of Ogbese River, and assessed the concentrations of heavy metal in water, sediments, pollution indices (contamination factor, geoaccumulation index, and potential ecological risk index). The metals assessed are zinc ( $\mathrm{Zn})$, cadmium $(\mathrm{Cd})$, chromium $(\mathrm{Cr})$, lead $(\mathrm{Pb})$, iron $(\mathrm{Fe})$, Arsenic (As), manganese (Mn), and copper $(\mathrm{Cu})$. These metals were chosen for investigation because some are essential ( $\mathrm{Fe}, \mathrm{Zn}, \mathrm{Cu}$ ) but may be dangerous to organisms at a high concentration, while others at low concentration may be toxic to living organisms and the environment. Lastly, the concentration levels were compared with the World Health Organization (WHO) regulatory limits of water, sediments, and fish to determine the toxicity level.

\section{Materials and Methods}

\subsection{Study Area}

Ogbese River is situated in the central and northern zones of Ondo state, South-West Nigeria (Oyelami et al. 2013). It lies between longitude $5^{\circ} 26^{\prime} \mathrm{E}$ and latitude $6^{\circ} 43^{\prime} \mathrm{N}$. The river runs through Ogbese Town, which is about $5 \mathrm{~km}$ from Akure, in Akure North Local Government Area of Ondo State, Nigeria (see Fig. 1). This river is one of the significant perennial rivers in South-Western, Nigeria. The source of the river is from Awo Ekiti in Ekiti State, Nigeria, and flows for approximately $22 \mathrm{~km}$ from its source to meet River Ose which is $265 \mathrm{~km}$ long and discharges into the Atlantic Ocean through complex chains of creeks and lagoons (Olawusi-Peters et al. 2015). The river serves agricultural purposes and source of water supply to the fish, farmers, and other agricultural industries located within Ayede-Ogbese. More so, solid agricultural and industrial waste sometimes causes a severe change in the water quality. Previous studies in Ogbese River showed that it runs through many communities (Orjiekwe et al. 2013). Ololade and Ajayi (2009), for example, investigated the contamination profile of significant rivers along the highways of Ondo State using water, surface sediment, and African catfish (Clarias gariepinus) from Ogbese River as partial environmental indicators.

\subsection{Sample Collection}

All samples (water, sediments, and fish) were collected from Ogbese River between April and October 2019. Forty-two water and sediment samples were collected from three sampling locations of the river. The period when the samples were collected was the wet season; this is the time water levels increase with heavy rainfall and flow of water is higher during this season.

Surface water samples were collected in litre bottle samples in triplicate. The samples were collected once a month (Ali et al. 2016) and transported in an ice-packed thermocool cooler to the laboratory of Animal and Environmental Biology, Adekunle Ajasin University, Akungba, Akoko, and kept in the refrigerator at $4{ }^{\circ} \mathrm{C}$ until the final analysis. The sediments were collected in triplicate using Ekma grab from different points in the river. The sediment samples were kept in a polythene bag and also transported to the laboratory. Also, 
Fig. 1 Sampling points along Ogbese River during the study (Google Earth)

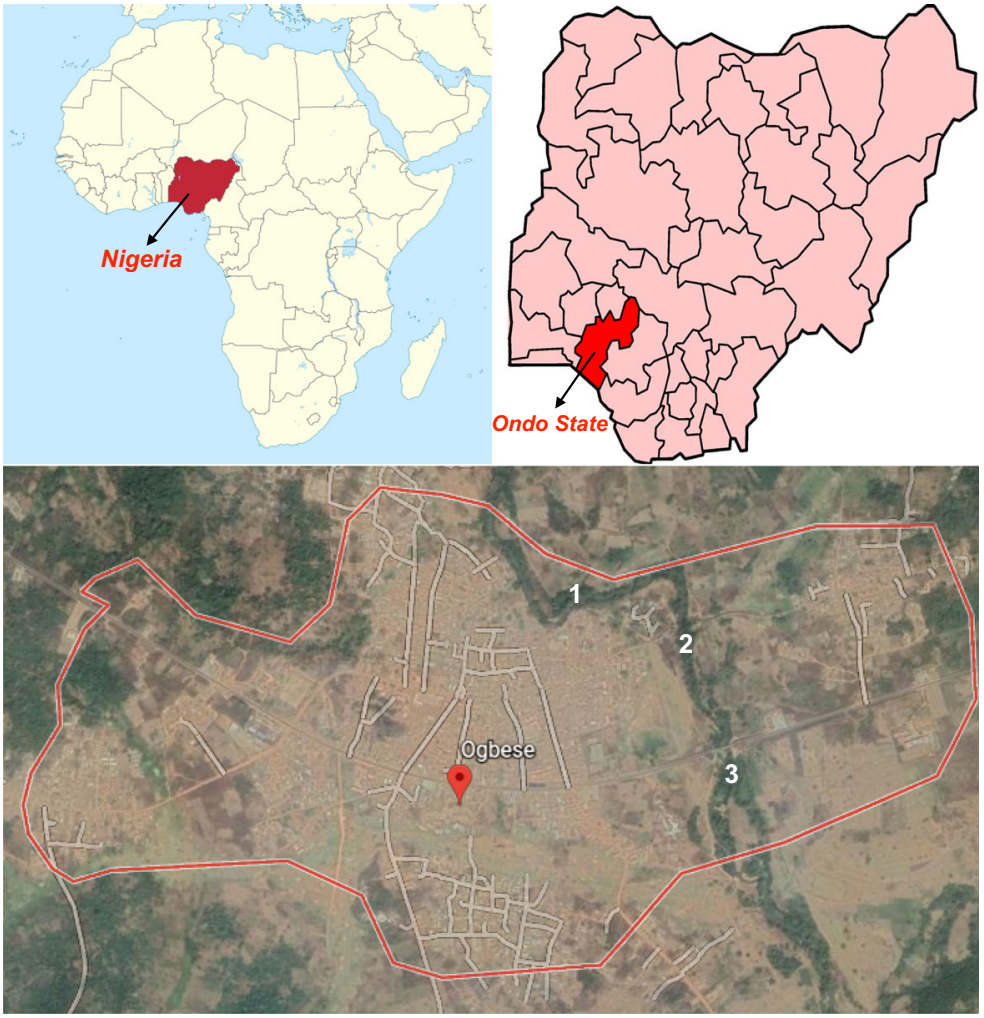

different fish samples were collected from the river and transported with an ice pack to the laboratory.

The sediments were air-dried, ground, and sieved in a $2-\mathrm{mm}$ mesh sieve to obtain a fine homogeneous powder in the laboratory. Digestion was done using the methods described by Yi et al. (2011) and AOAC (2005). The heavy metal concentrations were determined from the digest using an Atomic Absorption Spectrophotometer (Bulk Scientific VGB 211 model). Also, the water samples stored in the refrigerator were removed during the analysis and filtered using Whatman filter paper. Fifty millilitres of the filtrate was acidified using $\mathrm{HNO}_{3}$. Water digestion was done according to the methods described by $\mathrm{Yi}$ et al. (2011) and AOAC (2005).

Fish samples were weighed and dissected, and the tissues (kidney, livers, gills, and hearts) and the muscles (flesh) were stored in sample bottles containing $70 \%$ ethanol. The samples were rinsed with deionised water, weighed, acid-washed, and put into the Kjeldahl flask for digestion according to the methods of Ali et al. (2016) and Yi et al. (2011). The cooled samples were later paced in the AAS for heavy metal detections.

\subsection{Heavy Metal Analysis}

All the digested samples (fish tissues, sediments, and water) were analysed for heavy metals $(\mathrm{Cd}, \mathrm{Cr}, \mathrm{Zn}, \mathrm{Mn}$, $\mathrm{Fe}, \mathrm{Pb}$, and $\mathrm{As}$ ) using the Buck 211 atomic absorption spectrophotometer (AAS). Through the section tube, each metal was read at their respective wavelengths with their respective hollow cathode lamp using appropriate fuel and oxidant combination.

\subsection{Bioaccumulation Factor Determination}

In this present study, the bioaccumulation factors (BAF) of heavy metal concentrations were determined from the ratio of pelagic fishes to the freshwater (Tilapia zillii and Hepsetus odoe) and from the benthic fish species to sediments (Clarias gariepinus and Parachanna obscura). The BAF formula is expressed as:

$$
\begin{aligned}
& \mathrm{BAF}=\mathrm{Cn}_{\text {pelagic fish }} / \mathrm{Cn}_{\text {water }} \\
& \mathrm{BAF}=\mathrm{Cn}_{\text {benthic fish }} / \mathrm{Cn}_{\text {sediments }}
\end{aligned}
$$

where $\mathrm{Cn}_{\text {pelagic fish }}$ is the concentrations of heavy metals in pelagic fishes, $\mathrm{Cn}$ water is the concentrations of 
heavy metals in water, $\mathrm{Cn}_{\text {benthic }}$ is the concentration of heavy metals in benthic fish, and $\mathrm{Cn}_{\text {sediments }}$ are the heavy metal concentrations in sediments.

\subsection{Contamination Factor and Geoaccumulation Index}

The contamination status of sediments from the river was ascertained by determining the following: contamination factor (CF) introduced by Hakanson (1980) and geoaccumulation index $\left(I_{\mathrm{geo}}\right)$ described by Muller (1969). Contamination factor (CF) and geoaccumulation index $\left(I_{\text {geo }}\right)$ are indicators used to determine the presence and concentration of human-induced pollutant deposition in surface soil. These indexes are thus calculated as follows:

\subsubsection{Contamination Factor}

The formula was described by Hakanson (1980) as:

$\mathrm{CF}=C_{\mathrm{S}} / C_{\mathrm{B}}$

where $C_{\mathbf{S}}$ refers to the concentrations of trace/toxic heavy metal in the soil samples and $C_{\mathrm{B}}$ refers to the baseline or background value.

In this study, the world shale average background concentration values used by Abbasloua et al. (2014) and Onyari et al. (2003) were adopted and are internationally accepted.

To know the degree of contamination in sediments, four categories are adopted to describe this:

$\mathrm{CF}<1$ refers to low contamination factor; $1 \leq \mathrm{CF}<3$ indicates moderate contamination factor; $3 \leq \mathrm{CF} \leq 6$ shows considerable high contamination factor; and $\mathrm{CF}=$ 6 shows very high contamination (Adeyi and Babalola 2017; Nasr et al. 2006) (Table 1).

Table 1 International geochemical background shale values

\begin{tabular}{ll}
\hline Study trace/heavy metal & $\begin{array}{l}\text { Geochemical background } \\
\text { shale limit }(\mathrm{mg} / \mathrm{kg})\end{array}$ \\
\hline Zinc & 55.7 \\
Iron & 40,000 \\
Lead & 22.4 \\
Manganese & 886.1 \\
Cadmium & 0.28 \\
Copper & 45 \\
As & 8.1 \\
Cr & 93.9 \\
\hline
\end{tabular}

Sources: Abbasloua et al. (2014) and Onyari et al. (2003)

\subsubsection{Geoaccumulation Index}

The $I_{\text {geo }}$ was first defined and used by Müller (1969) to access metal pollution concentrations in sediment and developed global standard shale values (Singh et al. 2017; Praveena et al. 2007). This index is expressed as follows:

$I_{\text {geo }}=\log _{2}(\mathrm{Cn} / 1.5 \mathrm{Bn})$

where $\mathrm{Cn}=$ the measured concentration of the element in the soil; $\mathrm{Bn}=$ the geochemical background value; and the constant 1.5 is introduced to analyse natural variations of the background values in the environment and to detect a minimal human-made impact. In addition to the calculation, Müller (1979) also defined the seven classes of $I_{\text {geo }}$, presented in Table 2 .

\subsection{Ecological Risk Index}

The potential ecological risk index was another method designed by Hakanson (1980) from the study of sediment in order to evaluate the features and the ecofriendly nature of heavy metal contaminants. Furthermore, he investigated the toxic effect of heavy metal and its potential on the environment. The technique consists of a single contamination coefficient, heavy metal toxicity response factor, a more elaborate pollution measure, and potential ecological risk index. In this study, the potential ecological risk index $\left(E_{f}^{i}\right)$ for single heavy metal pollution is thus calculated as follows:

$E_{f}^{i}=T_{f}^{i} \times C_{f}^{i}$

where $E_{f}^{i}$ is the potential ecological risk index, $T_{f}^{i}$ is the response coefficient for the toxicity of the single metal, and $C_{f}^{i}$ is the pollution index and can be defined as follows:

$C_{f}^{i}=C_{s}^{i} \times C_{n}^{i}$

where $C_{s}{ }^{i}=$ the concentration of heavy metal in the sediment and $\mathrm{B}^{i}$ is the background/reference value.

The concentration of heavy background metal and the response coefficient for the toxicity of single metal (Jiao et al. 2012; Dong et al. 2007) is shown in Tables 3 and 4. 
Table 2 Classes of $I_{\text {geo }}$

\begin{tabular}{lll}
\hline Class & Value & Sediment and water quality \\
\hline 0 & $I_{\text {geo }} \leq 0$ & Uncontaminated \\
1 & $0<I_{\text {geo }}<1$ & Uncontaminated to moderately contaminated \\
2 & $1<I_{\text {geo }}<2$ & Moderately contaminated \\
3 & $2<I_{\text {geo }}<3$ & Moderately to heavily contaminated \\
4 & $3<I_{\text {geo }}<4$ & Heavily contaminated \\
5 & $4<I_{\text {geo }}<5$ & Heavily to extremely contaminated \\
6 & $I_{\text {geo }} \geq 5$ & Extremely contaminated \\
\hline
\end{tabular}

\subsection{Statistical Analysis}

The data from this present study were analysed using the SPSS 24 statistical package. Using the analysis of variance (ANOVA), the means and standard deviations of all heavy metal concentrations in fish organs, water, and sediments were detected. More so, the Pearson correlation was used to assess the relationships between the weight of a benthic fish and sediments as well as pelagic fish and water samples. Also, Microsoft Excel was used to design some of the figures in this study.

\section{Results and Discussion}

\subsection{Fish Diversity and Abundance}

Table 5 shows the six families and eight fish species collected during this study and their total weight. It could be seen that the families Clariidae (Clarias gariepinus and Clarias angularis) and Cichlidae (Tilapia zillii and Oreochromis niloticus) were the most abundant. Clariidae family, for example, are most abundant in freshwater bodies in Africa and South East Asia and are more diversified in the African continent with at

Table 3 Background values of heavy metal and response coefficient for the toxicity

\begin{tabular}{lll}
\hline Element & $\begin{array}{l}\text { Background/reference } \\
\text { value }\left(B_{n}{ }^{i}\right)\end{array}$ & $\begin{array}{l}\text { Coefficient for } \\
\text { toxicity }\left(T_{f}^{i}\right)\end{array}$ \\
\hline $\mathrm{Cd}$ & 0.28 & 30.0 \\
$\mathrm{Cr}$ & 93.9 & 2.0 \\
$\mathrm{Cu}$ & 40.9 & 5.0 \\
$\mathrm{~Pb}$ & 22.4 & 5.0 \\
$\mathrm{Zn}$ & 55.7 & 1.0 \\
\hline
\end{tabular}

Table 4 Potential ecological risk range and risk level

\begin{tabular}{ll}
\hline $\begin{array}{l}\text { Range of potential ecological } \\
\text { risk index }\left(\begin{array}{c}i \\
f\end{array}\right)\end{array}$ & $\begin{array}{l}\text { Ecological risk level single } \\
\text { factor pollution }\end{array}$ \\
\hline 40 & Low \\
$40 \leq \quad{ }^{i}<80$ & Moderate \\
$80 \leq \quad{ }^{i}<160$ & Considerable \\
$160 \leq \quad{ }^{i}<320$ & High \\
$320 \leq{ }^{i}$ & Serious \\
\hline
\end{tabular}

least 14 genera (Offem et al. 2010). According to Offem et al. (2010) supported by Venden and Bernacsek (1990), Clariidae is cost-effective, valuable for consumption, and very important in fish culture. The two species, $C$. gariepinus and $C$ angullaris identified in this study are the most suitable to culture in Nigeria because they can survive harsh conditions, are resistant to disease, increase growth rate and maximum yield, and are highly productive and nutritious (Offem et al. 2010). Figure 2 shows that $C$. gariepinus were the most abundant species observed in this study.

On the other hand, the Cichlidae family are of great economic importance and abundant in Africa. According to Turner et al. (2001), there are more than 2000 species of the cichlids and Froese and Pauly (2006) recognised about 200 genera. They further observed that new species have always been discovered. Within the African continent, over 1600 species of this family have been identified. In Nigeria, this family is commonly known as Tilapia. The species observed in this study, i.e. Oreochromis niloticus and Tilapia zillii, are usually abundant in the wet and dry season and they were the second most abundant species in this study. The other species were few, and this may be because the rivers are overflowing during the wet season. Tilapia zillii was the second most abundant, and it was seen throughout the study collection.

\subsection{Metal Concentrations in Water}

Heavy metal concentration in water samples from Ogbese River is presented in Table 6. Chromium mean concentrations ranged from 0.10 to $0.21 \mathrm{ppm}$. However, no significant difference $(p<0.05)$ was seen when the means were compared. It was observed from this study that the mean concentrations were higher than the permissible limit in Table 7. The result from this present study is similar to a study by Maurya et al. (2019) who observed that $\mathrm{Cr}$ values $(0.28-0.31 \mathrm{ppm})$ were higher in 
Table 5 Families and species of fish identified in this study

\begin{tabular}{|c|c|c|c|c|}
\hline $\mathrm{S} / \mathrm{N}$ & Families & Species & Zone & Total weight $(\mathrm{g})$ \\
\hline \multirow[t]{2}{*}{1} & \multirow[t]{2}{*}{ Clariidae } & Clarias gariepinus & Benthic & 1822 \\
\hline & & Clarias angularis & Benthic & 379 \\
\hline \multirow[t]{2}{*}{2} & \multirow[t]{2}{*}{ Cichlidae } & Tilapia zillii & Pelagic & 1024 \\
\hline & & Oreochromis niloticus & Pelagic & 122 \\
\hline 3 & Channidae & Parachanna obscura & Pelagic & 202 \\
\hline 4 & Hepsetidae & Hepsetus odoe & Pelagic & 73 \\
\hline 5 & Mormyridae & Mormyrus rume & Benthic & 40 \\
\hline 6 & Claroteidae & Parauchenoglanis ansorgii & Benthic & 167 \\
\hline
\end{tabular}

Source: Field data 2019

the river than the permissible limit (FAO 1983). Higher values of $\mathrm{Cr}$ can pose a significant health risk to human health. The mean concentrations of $\mathrm{Cd}$ range from 0.001 to $0.004 \mathrm{ppm}$; the results revealed that all mean concentration was within the permissible limit of $0.003 \mathrm{ppm}$ except for the water samples collected in September. Copper ranged from $0.150-2.00 \mathrm{ppm}$ and was below the permissible limit of $3.0 \mathrm{ppm}$ recommended by the WHO. The concentration of $\mathrm{Pb}$ varied across as the mean concentrations were higher in some months (June, September, and October) than the regulatory limits $0.1 \mathrm{ppm}$. A high concentration of $\mathrm{Pb}$ in water is dangerous for aquatic lives and human as earlier discussed. The concentrations of $\mathrm{Mn}$ and $\mathrm{Zn}$ ranged from 0.081 to $0.333 \mathrm{ppm}$ and 0.105 to $0.264 \mathrm{ppm}$, respectively. These metals were also below the permissible limits of $5 \mathrm{ppm}$ recommended by the WHO (WHO 2011). Furthermore, the mean concentrations of As and Fe were 0.041-0.135 ppm and 0.167$0.251 \mathrm{ppm}$, respectively. The mean concentrations of this present study are below the WHO limit of 10 ppm each.
The pattern order of the accumulated metal was $\mathrm{Fe}>\mathrm{Cu}$ $>\mathrm{Zn}>\mathrm{Mn}>\mathrm{Cr}>\mathrm{As}>\mathrm{Pb}>\mathrm{Cd}$. The pattern in this study is similar to the findings of Ali et al. (2016) and Islam et al. (2015) who reported a high concentration of heavy metals in their findings.

Source WHO (2003) and WHO (2006)

\subsection{Metal Concentrations in Sediment}

The mean concentrations of heavy metals examined in sediments from Ogbese River are presented in Table 8. The results showed the varying degrees of accumulation of heavy metals in the different months when compared to the WHO regulatory limits. Besides Fe mean concentrations ranging from 219.54 to $390.75 \mathrm{ppm}$, the highest mean value, for example, was recorded in July while the lowest mean was seen in June. Metal concentration was low in June, which is the peak rainfall month in Nigeria, and this may be as a result of high flow of water in the river. When these concentrations were compared to the

Fig. 2 Fish species collected monthly

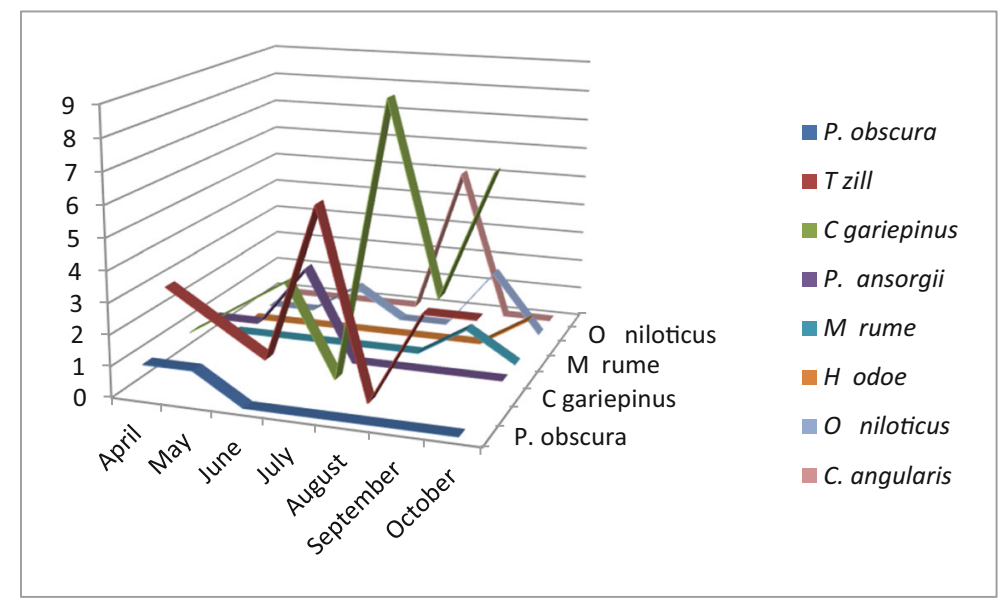


Table 7 Permissible limits of heavy metals in water and sediment

\begin{tabular}{lll}
\hline Element & Water (WHO) $(\mathrm{ppm})$ & $\begin{array}{l}\text { Sediments } \\
(\mathrm{WHO})(\mathrm{ppm})\end{array}$ \\
\hline Iron $(\mathrm{Fe})$ & 5.00 & 5.00 \\
Zinc $(\mathrm{Zn})$ & 5.00 & $\leq 1$ \\
Copper $(\mathrm{Cu})$ & 3.00 & $0.05-0.15$ \\
Arsenic $(\mathrm{As})$ & 10 & 20.00 \\
Manganese $(\mathrm{Mn})$ & 5.00 & 0.2 \\
Cadmium $(\mathrm{Cd})$ & $0.001-0.005$ & 0.1 \\
Chromium $(\mathrm{Cr})$ & 0.1 & $0.03-0.3$ \\
Lead $(\mathrm{Pb})$ & 0.1 & 5.00
\end{tabular}

WHO regulatory limits of $5.0 \mathrm{ppm}$, it was observed that the concentrations in the sediments were higher. From this study, it was observed that Fe has the highest mean concentrations than other metals examined. This agrees with the findings of Olatunji-Ojo et al. (2019) that reported high concentrations of $\mathrm{Fe}$ in all the three sampling rivers in Ilaje LGA, Nigeria. It is essential to know that the Nigerian soil has a very high concentration of $\mathrm{Fe}$ and this may be due to the chemical composition of the country's parent soils (Olayinka-Olagunju et al. 2019; Irmak et al. 2008). Although Fe is an essential metal, it should not be too high in the sediments as this may affect benthic fish or other aquatic lives that are at the bottom of the river. More so, increased concentration in $\mathrm{Fe}$ may as well cause oxidative stress in the fish (Igharo et al. 2014).

Manganese mean concentrations ranged from 0.58 to $1.69 \mathrm{ppm}$. The table reveals that the mean concentrations obtained from this study were higher than the permissible regulatory limit of $0.2 \mathrm{ppm}$. The table also reveals that the highest mean concentrations were recorded in July with $(1.69 \pm 0.74 \mathrm{ppm})$ while the lowest mean was seen in June $(0.58 \pm 0.13 \mathrm{ppm})$. It is essential to know that besides being an essential metal needed by animals in the biological systems, the concentration should not be higher than the required limit. Raji et al. (2010) believe that burning of charcoal and disposal of battery waste are the primary source of Mn. This study is similar to the study of Wogu and Okaka (2011), whose results show that Mn levels obtained from their studies were higher than the WHO limits. The result from this study, therefore, implies that sediments from Ogbese River are contaminated with Mn.

The highest mean concentration for $\mathrm{Zn}$ was recorded in July $(1.30 \pm 0.13 \mathrm{ppm})$, while the lowest mean value was recorded in June $(0.92 \pm 0.25 \mathrm{ppm})$. When these 
Table 8 Heavy metal concentration in Ogbese sediments

\begin{tabular}{|c|c|c|c|c|c|c|c|c|}
\hline \multirow[t]{2}{*}{ Month } & \multicolumn{8}{|c|}{ Heavy metals (ppm) } \\
\hline & $\mathrm{Fe}$ & $\mathrm{Zn}$ & $\mathrm{Mn}$ & $\mathrm{Pb}$ & As & $\mathrm{Cd}$ & $\mathrm{Cr}$ & $\mathrm{Cu}$ \\
\hline April & $235.12 \pm 68.68$ & $1.02 \pm 0.45$ & $0.73 \pm 0.10$ & $0.57 \pm 0.17$ & $0.42 \pm 0.25$ & $0.42 \pm 0.14$ & $0.42 \pm 0.14$ & $0.60 \pm 0.14$ \\
\hline May & $301.74 \pm 14.10$ & $1.21 \pm 0.08$ & $1.21 \pm 0.08$ & $0.30 \pm 0.17$ & $0.10 \pm 0.00$ & $0.35 \pm 0.17$ & $0.43 \pm 0.08$ & $0.69 \pm 0.19$ \\
\hline June & $219.54 \pm 113.78$ & $0.92 \pm 0.25$ & $0.58 \pm 0.13$ & $0.27 \pm 0.04$ & $0.09 \pm 0.01$ & $0.31 \pm 0.16$ & $0.31 \pm 0.16$ & $0.71 \pm 0.18$ \\
\hline July & $390.75 \pm 43.65$ & $1.30 \pm 0.13$ & $1.69 \pm 0.74$ & $0.37 \pm 0.02$ & $0.23 \pm 0.20$ & $0.41 \pm 0.0$ & $0.41 \pm 0.06$ & $1.28 \pm 0.02$ \\
\hline August & $301.74 \pm 14.14$ & $1.21 \pm 0.08$ & $0.70 \pm 0.33$ & $0.24 \pm 0.05$ & $0.34 \pm 0.06$ & $0.45 \pm 0.03$ & $0.45 \pm 0.03$ & $0.98 \pm 0.14$ \\
\hline September & $300.01 \pm 12.12$ & $1.00 \pm 0.00$ & $1.01 \pm 0.56$ & $0.29 \pm 014$ & $0.01 \pm 0.06$ & $0.37 \pm 0.10$ & $0.39 \pm 0.10$ & $0.89 \pm 0.11$ \\
\hline October & $256.76 \pm 13.09$ & $1.02 \pm 0.45$ & $0.97 \pm 0.13$ & $0.35 \pm 0.08$ & $0.58 \pm 0.13$ & $0.43 \pm 0.13$ & $0.33 \pm 0.08$ & $0.91 \pm 0.08$ \\
\hline WHO/FAO limit (ppm) & 5 & $<1$ & 0.2 & 5 & $0.2-1.5$ & 0.1 & 0.1 & 20 \\
\hline
\end{tabular}

Source: Fieldwork Data 2019

concentrations were compared to the limits $\leq 1 \mathrm{ppm}$, the concentrations were higher. Zinc, an essential metal, is regulated by many organisms because it does not biomagnify in the aquatic organism. This is because many aquatic animals absorb $\mathrm{Zn}$ majorly from water and sediments but not in what they consume (Vardi and Chenji 2020). Ana et al. (2011) were of the view that the bioavailability of dissolved $\mathrm{Zn}$ depends on some physical and chemical characteristics like $\mathrm{pH}$, hardness, and dissolved oxygen. More so, Akan et al. (2010) have argued that alloys like brass and bronze, fungicide, and batteries may be the sources of $\mathrm{Zn}$ in sediment. This present study is similar to the results obtained by Ochieng et al. (2007) whose mean concentrations of $\mathrm{Zn}$ were higher than the permissible limit.

Arsenic mean values ranged from $0.09 \mathrm{ppm}$ in June to $0.42 \mathrm{ppm}$ in April. From the table, it can be deduced that the mean concentrations from the sediments were lower than the WHO limits of $10 \mathrm{ppm}$. Arsenic, for example, may occur in different minerals as metalloid or seen in ashes from the combustion of highly hazardous coal. These results, however, differ from the study of Thinh et al. 2016, who reported high concentrations (6.9-31.0 ppm) of As.

Furthermore, the mean concentrations of $\mathrm{Cr}$ ranged from 0.31 to $0.45 \mathrm{ppm}$. Results from this study were, however, higher than the regulatory limits of $0.1 \mathrm{ppm}$. Chromium, for instance, is used as metal alloys and pigments for paints, cement, paper, rubber, and other materials. Exposure to a low concentration of $\mathrm{Cr}$ may cause skin irritation and cause ulceration. More so, longterm exposure is capable of causing kidney and liver damage and also disruptions of circulatory and nerve tissues (ATSDR 2000). Bioaccumulation of Cr in aquatic life is hazardous and may contribute to the danger of eating fish.

Cadmium concentration was observed to be above the permissible limit $0.05 \mathrm{ppm}$. The highest concentration $(0.49 \mathrm{ppm})$ was seen in September; while in $\mathrm{Au}-$ gust, the least concentration $(0.26 \mathrm{ppm})$ was observed. This result is similar to the study of Vardi and Chenji (2020) who reported high concentrations of Cd in India. Cadmium is usually grouped as a toxic trace element, found in low concentration in rocks, coal, and petroleum and sometimes combines with $\mathrm{Zn}$ (Sobha et al. 2016). However, no previous study has shown any beneficial values of $\mathrm{Cd}$. It is also important to know that $\mathrm{Cd}$ bioaccumulates with age and it affects the kidney and liver as well as cardiovascular diseases (Obahiagbon and Olowojoba 2007).

The mean concentrations of $\mathrm{Cu}$ ranged from 0.80 to $1.28 \mathrm{ppm}$ while $\mathrm{Pb}$ also ranged from 0.24 to $0.57 \mathrm{ppm}$. When the mean concentrations of these metals were compared to the permissible limits, it was observed that both metals were below the limits. This implies that the sediments were not contaminated with $\mathrm{Cu}$ or $\mathrm{Pb}$. It is important to note that the concentration of $\mathrm{Pb}$ recorded in this study may be affecting lower organisms. Copper is essential to fish and human as earlier discussed, but at high concentration, it will be dangerous to both. Bioaccumulation of $\mathrm{Cu}$ may lead to vomiting, haematemesis (vomiting of blood), low blood pressure, coma, jaundice, and gastrointestinal distress (Igharo et al. 2014).

On the other hand, $\mathrm{Pb}$, a well-known toxicant, has several harmful effects on human health even at low concentrations. Bioaccumulation of $\mathrm{Pb}$ may be due to 
long-term exposure and sometimes cause death or permanent damage to the central nervous system, the brain, kidneys, and liver and could be genotoxic (Olatunji-Ojo et al. 2020). In children, $\mathrm{Pb}$ is considered a serious health threat as its poisoning effect can last a lifetime. Lead concentration obtained in this study is similar to the result of Adekoya et al. (2006) in Ojora River in Lagos State, Nigeria. The order of heavy metals detected in sediment is $\mathrm{Fe}>\mathrm{Zn}>\mathrm{Mn}>\mathrm{Cu}>\mathrm{Cd}>\mathrm{Cr}>\mathrm{As}>\mathrm{Pb}$.

\subsection{Metal Concentrations in Fish Organs}

Table 9 and Fig. 2 show the results of heavy metal concentrations in fish tissues (livers, heart, and gills) and muscle (flesh). Out of the eight species caught in this study, four species were examined. These species were selected because they were caught throughout the months of this study.

From Fig. 3 and Table 9, it can be seen that $\mathrm{Cr}$ was not detected in the hearts of $C$. gariepinus, $H$. odoe, and $P$. obscura. However, in $O$. niloticus, the concentration detected was $0.002 \mathrm{ppm}$. The results show that the concentration was below the permissible limit of 0.05 $0.15 \mathrm{ppm}$. These low concentrations may be due to the high flow of water and movement of heavy metals at the time of collection of the fish samples. This result is similar to the observation of Yi et al. (2011) who suggested that low concentration of heavy metals in fish may be due to high flow disturbance and downstream movement of pollutants in water. Cadmium ranged from not detected (ND) to $0.001 \mathrm{ppm}$ ) among the fish heart. The metal was only detected in C. gariepinus $(0.001$ ppm) heart, and the concentration was below the limit of $0.05 \mathrm{ppm}$. This implies that the fish heart was not contaminated with cadmium. However, at low concentration, Cd may still be very dangerous, causing kidney damage and sometimes arthritis (Maurya and Malik 2016; Jarup 2003).

T. zillii's heart recorded the highest mean concentration of copper with $0.257 \mathrm{ppm}$, while the least mean concentration was observed in C. gariepinus $0.086 \mathrm{ppm}$ which indicate that it is within the limits of $3.0 \mathrm{ppm}$. However, significant differences $(p<0.05)$ were observed between $O$. niloticus and $H$. odoe when the four mean concentrations were compared; there were no significant differences $(p>0.05)$ observed in C. gariepinus and P. obscura. It is imperative to note that copper is one of the essential metals needed to help enzymatic activities in the animal system. Lead $(\mathrm{Pb})$ was not detected in C. gariepinus, O. niloticus, and H. odoe heart but was detected in P. obscura $(0.003 \mathrm{ppm})$, and it was below the permissible limit. It should be noted that if the concentration of $\mathrm{Pb}$ is higher than the stipulated level, the fish may have respiratory issues (Maurya and Malik 2018). Arsenic (As) was detected in the heart of all the fish species examined except in $H$. odoe. Consumption of arsenic over some time in fish or water may be carcinogenic to humans leading to skin cancer (Jarup 2003).

More so, the concentration of $\mathrm{Fe}, \mathrm{Mn}$, and $\mathrm{Zn}$ were lower in the fish heart than the permissible limits. These metals are trace elements important for the survival of the fish; also, $\mathrm{Fe}$ is an essential part of haemoglobin needed for oxygen transportation in the body. A high concentration of $\mathrm{Zn}$ in any organ of the fish may affect the hepatic distribution. The heavy metal concentration order in the heart is $\mathrm{Fe}>\mathrm{Zn}>\mathrm{Mn}>\mathrm{Cu}>\mathrm{As}>\mathrm{Pb}>\mathrm{Cr}>$ $\mathrm{Cd}$. This sequence is similar to the findings of Maurya and Malik (2018) and Jezierska and Witeska (2006). The trend implies that these essential trace metals are available in the environment and their roles cannot be ruled out.

The mean concentration of $\mathrm{Fe}$ in the liver of C. gariepinus ranged from 0.001 to $0.365 \mathrm{ppm}$ ), T. zillii ranged from 0.001 to $0.622 \mathrm{ppm}, H$. odoe ranged from 0.001 to $0.736 \mathrm{ppm}$, and $P$. obscura ranged from 0.001 to $0.543 \mathrm{ppm}$ and were within the permissible limits. Iron is an essential metal needed by fish for blood production (Ali and Khan 2019). Cadmium ranged from ND to $0.001 \mathrm{ppm}$ and was only detected in $H$. odoe. The mean concentration of $\mathrm{Cu}$ ranged from 0.155 to 0.299 ppm, and these concentrations were below the regulatory limit of $5 \mathrm{ppm}$. Also, the concentrations of $\mathrm{Pb}$ ranged from ND to $0.029 \mathrm{ppm}$, As from 0.001 to $0.002 \mathrm{ppm}, \mathrm{Mn}$ from 0.198 to $512 \mathrm{ppm}$, and $\mathrm{Zn}$ from 0.269 to $519 \mathrm{ppm}$. It should, however, be noted that all these metals were within limits. These indicate that the fish livers were not contaminated with the heavy metals because they are below the stipulated regulatory limits. Besides, these concentrations may be toxic to lower animals. In the fish liver, the distribution pattern is $\mathrm{Fe}$ $>\mathrm{Zn}>\mathrm{Mn}>\mathrm{Cu}>\mathrm{As}>\mathrm{Cr}>\mathrm{Pb}>\mathrm{Cd}$, and it is identical to what was observed in the heart of fish as well as the studies of Maurya and Malik (2018) and Jezierska and Witeska (2006).

In the gills, it was observed that $\mathrm{Cr}$ ranged between 0.001 and $0.029 \mathrm{ppm}$. This mean value is below the stipulated regulatory value; however, a significant 


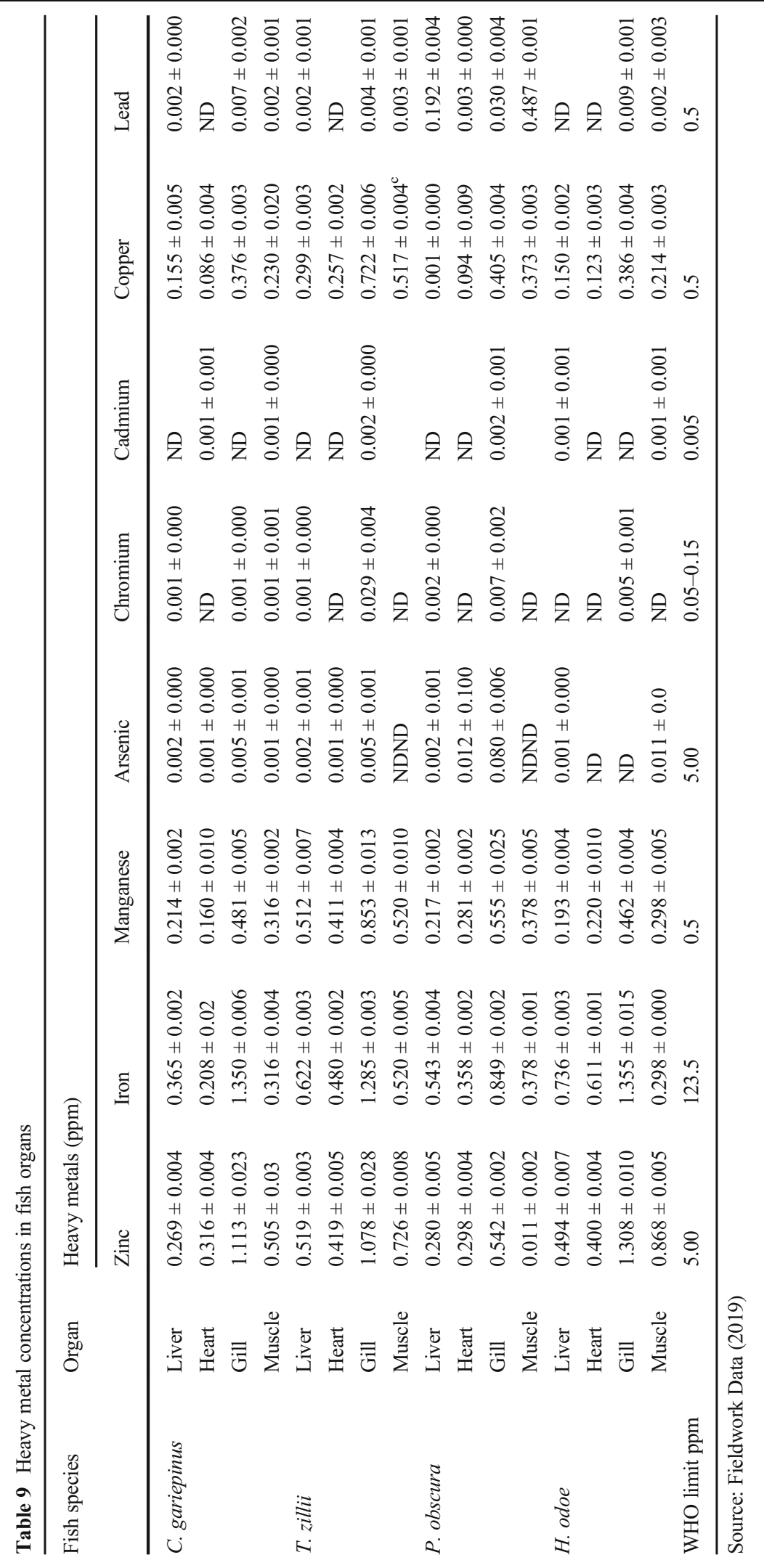


Fig. 3 Concentrations of heavy metal organs

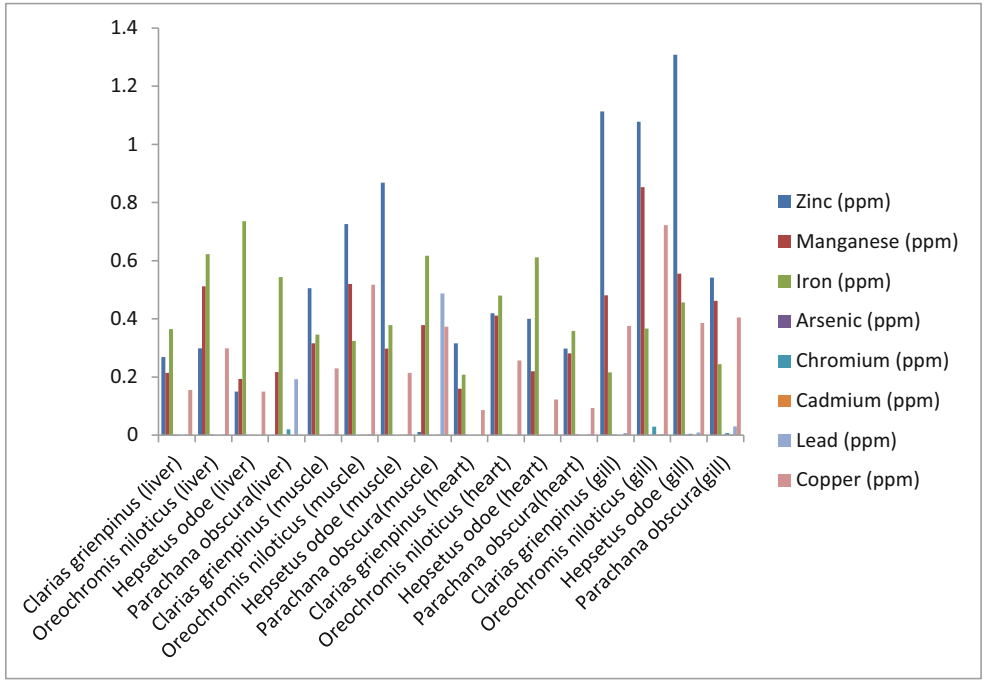

difference $(p<0.05)$ was observed between C. gariepinus and T. zillii when the mean concentrations were compared. On the other hand, no significant difference was seen between $H$. odoe and P. obscura. Cadmium was not detected in C. gariepinus and $H$. odoe but was seen in T. zillii and P. obscura with the same concentration of $0.002 \mathrm{ppm}$. These concentrations were below the permissible limit. Copper was observed in all the samples examined with $T$. zillii recording the highest mean concentration of $0.722 \mathrm{ppm}$, while the least concentration was observed in C. gariepinus with $0.376 \mathrm{ppm}$. The mean concentration of copper observed was below the permissible limit. However, a significant difference $(p<0.05)$ was observed in all the fish samples collected for copper examination when compared with each other. The mean concentration of $\mathrm{Pb}$ ranged from 0.004 to $0.030 \mathrm{ppm}$. When the mean concentrations of the heavy metal detected in the fish species were compared, significant differences $(p<0.05)$ were observed. However, the mean concentrations of $\mathrm{Pb}$ in the gill were below the permissible limit of $0.29 \mathrm{ppm}$ recommended by the WHO. Manganese ranged from 0.481 to $0.853 \mathrm{ppm}$, $\mathrm{Zn}$ ranged from 0.542 to $1.308 \mathrm{ppm}$, As from ND to $0.002 \mathrm{ppm}$, and $\mathrm{Fe}$ ranged from 0.849 to $1.355 \mathrm{pm}$. From the results, it was discovered that all heavy metals analysed were within the stipulated regulatory limits.

The mean concentrations of heavy metals in fish muscles are also present in Table 2. From the results, it was observed that the mean concentrations of $\mathrm{Cu}$ varied greatly from 0.230 to $0.373 \mathrm{ppm}$. The mean concentrations were found to be below the permissible limits.
There were significant differences $(p<0.001)$ among four fish species. Zinc mean concentration ranged from 0.505 to $0.11 \mathrm{ppm}$, and it is below the stipulated regulatory limit. The accumulation of zinc among fish species were significantly different $(p<0.005)$. The mean concentrations of $\mathrm{Pb}$ ranged from 0.02 to 0.487 . The lowest concentration was detected in $C$. gariepinus while the highest was in $P$. obscura. The significant difference $(p<0.001)$ was observed between the mean concentrations. Manganese concentrations in the muscle ranged from 0.316 to $0.378 \mathrm{ppm}$, and they were lower than the regulatory concentration.

\subsection{Bioaccumulation Factors of Metals in Pelagic and Benthic Fishes}

Bioaccumulation factors (BAFs) of heavy metals in pelagic fish to water and benthic fish to sediment are shown in Figs. 4 and 5. These figures show the specific

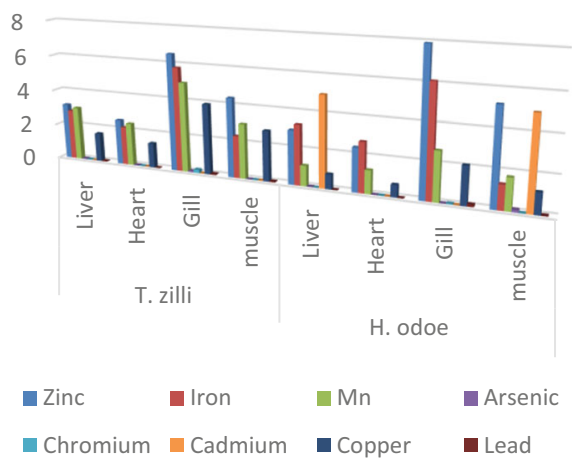

Fig. 4 BAFs of heavy from pelagic fish to water. Source: Field data 


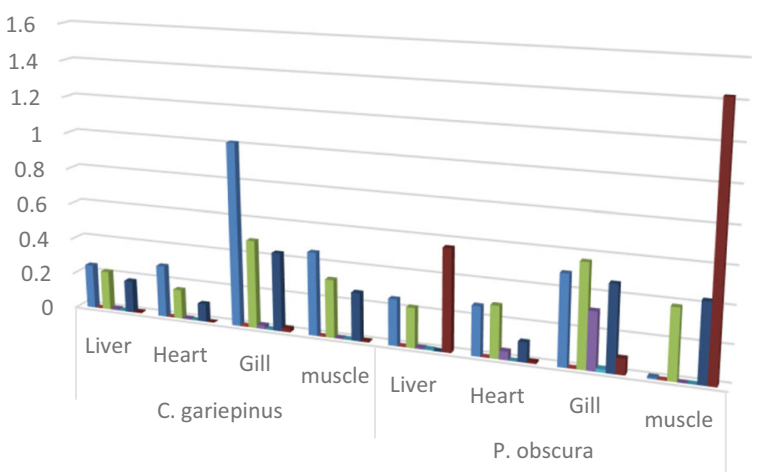

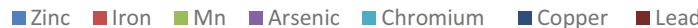

Fig. 5 BAFs of heavy from benthic fish to sediments

BAFs of heavy metals in each fish organs (heart, gill, liver, and muscle) and further revealed that the least BAFs was seen in the liver of T. zillii $(\mathrm{Cr}=0.0062)$ while the highest was found in the gill in $H$. odoe $(\mathrm{Zn}=$ 7.9129). From the heavy metal BAFs of the pelagic fish results, a high level of $\mathrm{Zn}$ was seen in the gills of the two fish species $(\mathrm{Zn}=7.9129$ and 6.5215). These results, however, showed no probability as all the values were below 1000. According to Arnot and Gobas (2006), BAFs of heavy metal are categorised as follows: BAF $<$ 1000: no probability of accumulation; $1000<$ BAF < 5000: bio-accumulative; BAF > 5000: extremely bioaccumulative. Therefore, from this study, according to the categories, all the heavy metal BAFs were less than 1000 (BAF < 1000), indicating no probability. Also, in both $T$. zillii and $H$. odoe, the pattern of BAF in the organs was reported to be gill, muscle, liver, heart, indicating that BAFs of heavy metals are very high in the gills and least in the heart of the pelagic fishes. The order of BAF overall concentrations of heavy metals in the organs followed the pattern gill $>$ muscles $>$ liver $>$ heart. The gill has the highest BAFs because it is widely opened to the river; hence, it is predisposed to the exposure of heavy metals in the aquatic environment. Also, the exposure of fish to a high concentration of $\mathrm{Zn}$ may lead to loss of weight due to loss of appetite (Yi and Zhang 2012). Results from this study are similar to what was observed by Ali et al. (2019); they observed that metabolically active tissues, i.e. gills, liver, kidneys, showed higher accumulations of heavy metals than other tissues such as muscles and skin (Ali et al. 2019). In T. zillii, the heavy metal patterns are $\mathrm{Mn}, \mathrm{Fe}$, $\mathrm{Zn}, \mathrm{Cu}, \mathrm{Cr}, \mathrm{As}, \mathrm{Cu}, \mathrm{Cd}$ while in $\mathrm{H}$. odoe, $\mathrm{Zn}, \mathrm{Fe}, \mathrm{Cd}$, $\mathrm{Mn}, \mathrm{Cu}, \mathrm{Pb}, \mathrm{As}, \mathrm{Cr}$. More so, the average BAFs of the heavy metals observed in the pelagic fish species were as follows: $\mathrm{Zn}(30.16030)>\mathrm{Fe}(26.6562)>\mathrm{Mn}$ $(20.2983)>\mathrm{Cu}(14.5079)>\mathrm{Cd}(10)>\mathrm{Pb}(0.2818)>$ As $(0.2541)>\mathrm{Cr}(0.2172)$. The $\mathrm{Zn}$ and $\mathrm{Fe}$ are slightly higher than other elements in the fish organs because they are important metals in living tissues (ATSDR 2005; Traina et al. 2019)

The ratio of benthic fish to the sediments is shown in Fig. 5. In C. gariepinus, the BAFs of the element were reported as follows: $\mathrm{Zn}, \mathrm{Mn}, \mathrm{Cu}, \mathrm{As}, \mathrm{Pb}, \mathrm{Cr}, \mathrm{Fe}, \mathrm{Cd}$; implying that $\mathrm{Zn}$, an essential element is the most abundant metal while $\mathrm{Cd}$ was the least detected. In the organs from C. gariepinus, the pattern showed gill, muscle, liver, heart. This result suggests that the gills of these fish have the highest BAFs and the heart is the least contaminated. In addition, $P$. obscura result revealed $\mathrm{Pb}$ $>\mathrm{Mn}>\mathrm{Zn}>\mathrm{Cu}>\mathrm{As}>\mathrm{Cr}>\mathrm{Fe}>\mathrm{Cd}$ pattern. From this order, it can be seen that $\mathrm{Pb}$, an element that is very toxic and harmful to the ecosystem and the entire living tissue, has the highest BAFs. The element, $\mathrm{Pb}$, for example, is usually abundant in areas where agricultural industries or activities are carried out just like this present study location. More so, $\mathrm{Pb}$ accumulation may result in illnesses like bone haematopoietic function disorder, nervous breakdown, mental retardation, and even death in human or other living organisms (Zhong et al. 2018). The overall BAFs heavy metals result of BAFs of fish to sediments also showed that the heavy metals were as observed as follows: $\mathrm{Zn}, \mathrm{Mn}, \mathrm{Pb}, \mathrm{Cu}, \mathrm{As}, \mathrm{Cr}, \mathrm{Fe}, \mathrm{Cd}$, while the concentrations in the organs were classified in the following order: gill $>$ muscle $>$ liver $>$ heart. Results from this present study were relatively lower than those of Ahmed et al. (2015) and Maurya et al. (2019) where the BAFs in living tissue were reported as liver, gill, and muscle and the elements as $\mathrm{Cu}(1971.42)>\mathrm{As}$ (1042.93) > Pb (913.66) > Cr (864.99) > Cd (252.03). Ali et al. (2019), however, suggested that the heavy metal accumulation in living organs should be higher in the following pattern: gills, liver, kidneys, than in the muscles.

\subsubsection{Contamination Indices}

Contamination Factor and Geoaccumulation Index The $\mathrm{CF}$ values for $\mathrm{Pb}, \mathrm{Cr}, \mathrm{Fe}, \mathrm{Zn}, \mathrm{Cu}, \mathrm{Mn}$, and As in this present study are low because the calculated values are less than one, indicating low contamination in spite of all anthropogenic activities in the river. However, Cd had the highest CF (1.556), and it indicated 
Table 10 Contamination factors (CF) and geoaccumulation index $\left(I_{\text {geo }}\right)$ in sediments and water

\begin{tabular}{lllll}
\hline Element & $\begin{array}{l}\text { Contamination } \\
\text { factors (sediments) }\end{array}$ & $I_{\text {geo }}$ (sediments) & $\begin{array}{l}\text { Contamination factors } \\
\text { (water) }\end{array}$ & $I_{\text {geo }}$ (water) \\
\hline $\mathrm{Cd}$ & 1.556 & 0.053 & 0.000557 & -11.3961 \\
$\mathrm{Cr}$ & 0.004 & -8.491 & 0.001716 & -9.7716 \\
$\mathrm{Cu}$ & 0.021 & -7.162 & 0.004495 & -8.38233 \\
$\mathrm{~Pb}$ & 0.020 & -6.621 & 0.003170 & -8.88643 \\
$\mathrm{Zn}$ & 0.020 & -6.251 & 0.002967 & -18.4696 \\
$\mathrm{Fe}$ & 0.009 & -7.453 & 0.000006 & -8.55872 \\
$\mathrm{Mn}$ & 0.001 & -10.399 & 0.000193 & -12.9254 \\
$\mathrm{As}$ & 0.031 & -5.587 & 0.009718 & -7.27012 \\
\hline
\end{tabular}

moderate contamination which might be attributed to the agricultural and waste disposal activities around the river (Table 10). Moreover, all metals were less than one in the water sample, implying low contamination.

The calculated sediments' $I_{\text {geo }}$ values for As, $\mathrm{Zn}, \mathrm{Fe}$, $\mathrm{Cu}, \mathrm{Mn}, \mathrm{Cr}$, and $\mathrm{Pb}$ did not get to grade 0 , which implies that the sediments were uncontaminated with these elements. However, the metal $\mathrm{Cd}$ attained grade 0 , showing that the quality of the sediments ranged from uncontaminated to moderately contaminated. The reason for this result is because all elements examined are within the background values for each metal, and that despite human activities, these elements are practically unchanged (Rabee et al. 2011). However, in the water samples, all metals did not attain the 0 grade level, thus, indicating that the water samples were not contaminated.

\subsubsection{Potential Ecological Risk of Heavy Metals in Water and Sediments}

The concentration of heavy background metal and the response coefficient for the toxicity of single metal (Jiao

Table 11 Potential ecological risk index

\begin{tabular}{lll}
\hline Element & $\begin{array}{l}\text { Potential ecological risk } \\
\text { index in sediment }\end{array}$ & $\begin{array}{l}\text { Potential ecological risk } \\
\text { index in water }\end{array}$ \\
\hline $\mathrm{Cd}$ & 46.68367 & 0.00343 \\
$\mathrm{Cr}$ & 0.008337 & 0.01670 \\
$\mathrm{Cu}$ & 0.105833 & 0.02248 \\
$\mathrm{~Pb}$ & 0.076212 & 0.01585 \\
$\mathrm{Zn}$ & 0.019697 & 0.002967 \\
\hline
\end{tabular}

et al. 2012; Dong et al. 2007) are shown in Table 3. The potential ecological risk index of the heavy metals in the sediment is revealed in Table 11. The potential ecological risks of $\mathrm{Pb}, \mathrm{Zn}, \mathrm{Cr}$, and $\mathrm{Cu}$ were below 40 , indicating low risk while that of $\mathrm{Cd}$ is above 40 , implying moderate risk. All metals examined in the water showed a low-risk index, indicating that the water does not pose a threat to all fish in it, but it may serve as a threat to lower organisms.

\subsection{Correlation coefficient}

Table 12 shows the correlation coefficient $(r)$ between $C$. gariepinus weight and heavy metal concentrations from Ogbese River sediments. The result showed that at $p<0.05$, a significantly positive correlation was determined between $\mathrm{Fe}$ and $\mathrm{Cu}(r=0.971)$ as well as Fe and $\mathrm{Zn}(r=0.954)$. No correlation was seen between fish weight and heavy metals. The significantly positive correlation between $\mathrm{Fe}$ and copper and $\mathrm{Fe}$ and $\mathrm{Zn}$ indicated that the metals might have been created from a similar source or parent materials. These results corroborate the findings of Onjefu et al. (2017), Adesuyi et al. (2015), and Adeyi and Torto (2014) who revealed that common source of pollution input of heavy metals is possible across different sampling sites in different parts of the same geographical location.

Table 13 shows the correlation coefficient between T. zillii (pelagic fish) weight and the mean concentrations of heavy metals. From the result, it could be observed that no correlation coefficient was seen between weight and the heavy metal concentrations. However, between $\mathrm{Fe}$ and $\mathrm{Cd}$, a strong positive correlation $(r=0.904)$ was observed at $P<0.01$; while at $p<0.05$, positive 
Table 12 Correlation coefficients of sediment heavy metal concentrations and benthic fish species (C. gariepinus)

\begin{tabular}{|c|c|c|c|c|c|c|c|c|c|c|}
\hline & & Weight & Manganese & Arsenic & Iron & Lead & Chromium & Cadmium & Copper & Zinc \\
\hline \multirow[t]{2}{*}{ Weight } & Pearson correlation & 1 & -0.157 & 0.109 & 0.262 & -0.723 & 0.460 & 0.914 & 0.368 & 0.455 \\
\hline & Sig. (2-tailed) & & 0.843 & 0.891 & 0.738 & 0.277 & 0.540 & 0.086 & 0.632 & 0.545 \\
\hline \multirow[t]{2}{*}{ Manganese } & Pearson correlation & & 1 & -0.061 & 0.910 & 0.108 & 0.251 & -0.378 & 0.847 & 0.770 \\
\hline & Sig. (2-tailed) & & & 0.939 & 0.090 & 0.892 & 0.749 & 0.622 & 0.153 & 0.230 \\
\hline \multirow[t]{2}{*}{ Arsenic } & Pearson correlation & & & 1 & 0.037 & 0.608 & 0.855 & 0.438 & -0.157 & 0.270 \\
\hline & Sig. (2-tailed) & & & & 0.963 & 0.392 & 0.145 & 0.562 & 0.843 & 0.730 \\
\hline \multirow[t]{2}{*}{ Iron } & Pearson correlation & & & & 1 & -0.159 & 0.479 & 0.028 & $0.971 *$ & $0.954 *$ \\
\hline & Sig. (2-tailed) & & & & & 0.841 & 0.521 & 0.972 & 0.029 & 0.046 \\
\hline \multirow[t]{2}{*}{ Lead } & Pearson correlation & & & & & 1 & 0.236 & -0.431 & -0.380 & -0.154 \\
\hline & Sig. (2-tailed) & & & & & & 0.764 & 0.569 & 0.620 & 0.846 \\
\hline \multirow[t]{2}{*}{ Chromium } & Pearson correlation & & & & & & 1 & 0.615 & 0.340 & 0.703 \\
\hline & Sig. (2-tailed) & & & & & & & 0.385 & 0.660 & 0.297 \\
\hline \multirow[t]{2}{*}{ Cadmium } & Pearson correlation & & & & & & & 1 & 0.067 & 0.299 \\
\hline & Sig. (2-tailed) & & & & & & & & 0.933 & 0.701 \\
\hline \multirow[t]{2}{*}{ Copper } & Pearson correlation & & & & & & & & 1 & 0.907 \\
\hline & Sig. (2-tailed) & & & & & & & & & 0.093 \\
\hline \multirow[t]{2}{*}{ Zinc } & Pearson correlation & & & & & & & & & 1 \\
\hline & Sig. (2-tailed) & & & & & & & & & \\
\hline
\end{tabular}

*Correlation is significant at the 0.05 level (2-tailed)

Table 13 Correlation coefficients of Ogbese River's heavy metal concentrations and a pelagic fish species (T. zillii)

\begin{tabular}{|c|c|c|c|c|c|c|c|c|c|c|}
\hline & & Tilapia Weight & Zinc & Iron & Manganese & Arsenic & Chromium & Cadmium & Lead & Copper \\
\hline \multirow{2}{*}{ Tilapia weight } & Pearson correlation & 1 & -0.060 & -0.179 & 0.072 & 0.103 & 0.045 & -0.159 & 0.459 & 0.436 \\
\hline & Sig. (2-tailed) & & 0.899 & 0.700 & 0.878 & 0.827 & 0.923 & 0.734 & 0.300 & 0.328 \\
\hline \multirow[t]{2}{*}{ Zinc } & Pearson correlation & & 1 & 0.739 & 0.711 & 0.705 & 0.439 & $0.831 *$ & 0.736 & 0.281 \\
\hline & Sig. (2-tailed) & & & 0.058 & 0.073 & 0.077 & 0.325 & 0.021 & 0.059 & 0.541 \\
\hline \multirow[t]{2}{*}{ Iron } & Pearson correlation & & & 1 & 0.731 & 0.328 & -0.074 & $0.904 * *$ & 0.579 & -0.303 \\
\hline & Sig. (2-tailed) & & & & 0.062 & 0.472 & 0.875 & 0.005 & 0.173 & 0.510 \\
\hline \multirow[t]{2}{*}{ Manganese } & Pearson correlation & & & & 1 & 0.052 & 0.492 & 0.548 & 0.458 & 0.049 \\
\hline & Sig. (2-tailed) & & & & & 0.911 & 0.263 & 0.203 & 0.301 & 0.917 \\
\hline \multirow[t]{2}{*}{ Arsenic } & Pearson correlation & & & & & 1 & 0.088 & 0.668 & $0.764^{*}$ & 0.482 \\
\hline & Sig. (2-tailed) & & & & & & 0.851 & 0.101 & 0.046 & 0.273 \\
\hline \multirow[t]{2}{*}{ Chromium } & Pearson correlation & & & & & & 1 & -0.057 & 0.150 & 0.646 \\
\hline & Sig. (2-tailed) & & & & & & & 0.903 & 0.749 & 0.117 \\
\hline \multirow[t]{2}{*}{ Cadmium } & Pearson correlation & & & & & & & 1 & $0.755^{*}$ & -0.013 \\
\hline & Sig. (2-tailed) & & & & & & & & 0.050 & 0.977 \\
\hline \multirow[t]{2}{*}{ Lead } & Pearson correlation & & & & & & & & 1 & 0.470 \\
\hline & Sig. (2-tailed) & & & & & & & & & 0.287 \\
\hline \multirow[t]{2}{*}{ Copper } & Pearson correlation & & & & & & & & & 1 \\
\hline & Sig. (2-tailed) & & & & & & & & & \\
\hline
\end{tabular}

*Correlation is significant at the 0.05 level (2-tailed)

$* *$ Correlation is significant at the 0.01 level (2-tailed) 
correlations were observed between $\mathrm{Zn}$ and $\mathrm{Cd}(r$ $=0.831)$, As and $\mathrm{Pb}(r=0.764)$, and $\mathrm{Cd}$ and $\mathrm{Pb}$ $(r=0.755)$.

\section{Conclusion}

Given the above discussion, the results suggested that heavy metal concentrations in the fish organs were within the regulatory limits, but this limit may, however, harm lower aquatic organism in the river. More so, results obtained from the sediment showed that $\mathrm{Zn}, \mathrm{Mn}, \mathrm{Fe}, \mathrm{Cr}$, and $\mathrm{Cd}$ exceeded the recommended WHO limits for sediments. Consequently, it is essential to note that if the level of contaminants deposited into the rivers is not reduced, it may lead to some health hazards. Heavy metal concentrations in the water were reduced, and this may be due to a high flow of water during this study. However, further studies should be conducted during the dry season. This study, therefore, concludes that the fish and water in Ogbese River at the time of this study ranged from uncontaminated to moderately contaminated. Nevertheless, constant monitoring of the sediments in the river by the environmental unit of the State Ministry of Water and Minerals Resources is necessary to report the concentrations of heavy metals in the sediments, and the community should be informed on the danger of dumping waste into the river.

Acknowledgements The authors wish to appreciate Mr. KD, the fisherman who assisted in getting the fish, water, and sediment samples at the study location. We also acknowledge the help of Mary, Ronke, Samson, Motun, Sunday, Gbayi, Seyi, and Deborah for assisting with the fieldwork. Lastly, we wish to appreciate Mr. Fesobi for helping out the laboratory analyses.

Authors' Contributions All authors carried out this study as a team. Author JOO designed the study, conducted the fieldwork, performed the statistical analysis, and wrote the methodology. Authors AAD wrote the introduction, read the first draft, and checked the manuscript for plagiarism. Author AMO wrote the discussion and proofread the entire manuscript draft. The final manuscript was read by all author and approved for publications.

\section{Compliance with Ethical Standards}

Conflict of Interest The authors declare that they have no conflict of interest
Open Access This article is licensed under a Creative Commons Attribution 4.0 International License, which permits use, sharing, adaptation, distribution and reproduction in any medium or format, as long as you give appropriate credit to the original author(s) and the source, provide a link to the Creative Commons licence, and indicate if changes were made. The images or other third party material in this article are included in the article's Creative Commons licence, unless indicated otherwise in a credit line to the material. If material is not included in the article's Creative Commons licence and your intended use is not permitted by statutory regulation or exceeds the permitted use, you will need to obtain permission directly from the copyright holder. To view a copy of this licence, visit http://creativecommons.org/licenses/by/4.0/.

\section{References}

Abbasloua, H., Martinb, F., Abtahic, A., \& Moor, F. (2014). Trace element concentrations and background values in the arid soils of Hormozgan Province of southern Iran. Archives of Agronomy and Soil Science, 60(8), 1125-1143. https://doi. org/10.1080/03650340.2013.864387.

Adekoya, J., Williams, A., \& Olusegun, A. (2006). Distribution of heavy metals in sediments of Igbede, Ojo and Ojora rivers of Lagos, Nigeria. The Environmentalist, 26, 277-280. https://doi.org/10.1007/s10669-006-9077-1.

Adesuyi, A. A., Njoku, K. L., \& Akinola, M. O. (2015). Assessment of heavy metals pollution in soils and vegetation around selected industries in Lagos State, Nigeria. Journal of Geoscience and Environment Protection, 3, 11-19.

Adeyi, A. A., \& Babalola, B. A. (2017). Lead and cadmium levels in residential soils of Lagos and Ibadan, Nigeria. Journal of Health and Pollution, 7(13), 42-55.

Adeyi, A., \& Torto, N. (2014). Profiling heavy metal distribution and contamination in soil of old power generation station in Lagos, Nigeria. America Journal of Science and Technology, $1,1-10$.

Ahmed, M. K., Baki, M. A., \& Islam, M. S. (2015). Human health risk assessment of heavy metals in tropical fish and shellfish collected from the river Buriganga, Bangladesh. Environmental Science and Pollution Research, 22, 15880 15890. https://doi.org/10.1007/s11356-015-4813-z.

Akan, J. C., Abdulrahman, F. I., Sodipo, O. A., Ochanya, A. E., \& Askira, Y. K. (2010). Heavy metals in sediments from river Ngada, Maiduguri Metropolis, Borno State, Nigeria. Journal of Environmental Chemistry and Ecotoxicology, 2(9), 131140.

Akinbile, C. O., \& Omoniyi, O. (2018). Quality assessment and classification of Ogbese river using water quality index (WQI) tool. Sustainable Water Resources Management. https://doi.org/10.1007/s40899-018-0226-8.

Ali, H., \& Khan, E. (2019). Trophic transfer, bioaccumulation, and biomagnification of non-essential hazardous heavy metals and metalloids in food chains/webs - Concepts and implications for wildlife and human health. Human and Ecological Risk Assessment: An International Journal, 25(6), 13531376.

Ali, M. M., Ali, M. L., Islamc, M. S., \& Rahman, M. Z. (2016). Preliminary assessment of heavy metals in water and sediment of Karnaphuli River. Environmental Nanotechnology, Monitoring \& Management, 5, 27-35. 
Ali, H., Khan, E., \& Ilahi, I. (2019). Environmental chemistry and ecotoxicology of hazardous heavy metals: environmental persistence, toxicity, and bioaccumulation. Journal of Chemistry, 1-14. https://doi.org/10.1155/2019/6730305.

Ana, G. R., Oloruntoba, E. O., Shendell, D., Elemile, O. O., Benjamin, O. R., \& Sridhar, M. K. (2011). Solid waste management problems in secondary schools in Ibadan, Nigeria. Journal of Environmental Health, 74(2), 24-28.

AOAC. (2005). Official methods of analysis (18th ed.). Arlington, VA: Association of Official Analytical Chemists.

Arnot, J. A., \& Gobas, F. A. (2006). A review of bioconcentration factor $(\mathrm{BCF})$ and bioaccumulation factor (BAF) assessments for organic chemicals in aquatic organisms. Environmental Reviews, 14, 257-297. https://doi.org/10.1139/a06-005.

ATSDR (Agency for Toxic Substances and Disease Registry) (2000). Toxicological profile for arsenic. U.S. Department of health and human services, Public Health Service, pp. A-5.

ATSDR. (2005) Agency for Toxic Substances and Disease Registry, Toxicological Profile for Zinc. U.S. Department of Health and Human Services, Public Health Service, Atlanta.

Authman, M. M. N. (2008). Oreochromis niloticus as a biomonitor of heavy metal pollution with emphasis on potential risk and relation to some biological aspects. Global Veterinaria, 2(3), 104-109.

Dong, J., Bian, Z., \& Wang, H. (2007). Comparison of heavy metal contents between different reclaimed soils and the control soil. Journal of China University of Mining and Technology, 36(4), 531-536.

El-Moselhy, K. M., Othman, A. I., El-Azem, H. A., \& ElMetwally, M. E. A. (2014). Bioaccumulation of heavy metals in some tissues of fish in the Red Sea, Egypt. Egyptian Journal of Basic and Applied Sciences, 1(2), 97-105. https://doi.org/10.1016/j.ejbas.2014.06.001.

Eneji, I. S., Sha'Ato, R., \& Annune, P. A. (2011). Bioaccumulation of heavy metals in fish (Tilapia Zilli and Clarias Gariepinus) organs from River Benue, North Central Nigeria. Pakistan Journal of Analytical \& Environmental Chemistry, 12(1 \& 2), 25-31.

FAO. (1983). Compilation of legal limits for hazardous substances in fish and fishery products. FAO fisheries circular No. 764 (p. 102). FAO: Rome.

Froese, R., \& Pauly, D. (2006). Species of Sarotherodon in fish base. October, 2006, 5-1.

Gao, H. (2001). Pollution chemistry and ecology toxicity of multisand river (pp. 95-96). Zhenzhou: Yellow River Hydraulic Publication (in Chinese).

Grigoratos, T., Samara, C., Voutsa, D., Manoli, E., \& Kouras, A. (2014). Chemical composition and mass closure of ambient coarse particles at traffic and urban-background sites in Thessaloniki, Greece. Environmental Science and Pollution Research, 21, 7708-7722. https://doi.org/10.1007/s11356014-2732-z.

Hakanson, L. (1980). An ecological risk index for aquatic pollution control. A sedimentological approach. Water Research, 14(8), 975-1001.

Igharo, G. O., Anetor, J. I., Osibanjo, O. O., Osadolor, H. B., \& Dike, K. C. (2014). Toxic metal levels in Nigerian electronic waste workers indicate occupational metal toxicity associated with crude electronic waste management practices. Biokemistri, 26(4), 107-113.

Irmak, S., Surucu, A. K., \& Aydin, S. (2008). The effect of iron contents of soils on the iron contents of plant of Cukurova Region of Turkey. International Journal of Soil Science, 3, 109-118.

Islam, M. S., Ahmad, M. k., \& Habibullah Al Mamun, M. (2015). Determination of heavy metals in fish and vegetables in Bangladesh and health implication. Human and Ecological Risk Assessment: An International Journal, 21(4), 986-1006.

Jaishankar, M., Tseten, T., \& Anbalagan, N. (2014). Toxicity, mechanism and health effects of some heavy metals. Interdisciplinary Toxicology, 7(2), 60-72. https://doi. org/10.2478/intox-2014-0009.

Jarup, L. (2003). Hazards of heavy metal contamination. British Medical Bulletin, 68(1), 167-182. https://doi.org/10.1093 /bmb/ldg032.

Jezierska, B., \& Witeska, M. (2006). The metal uptake and accumulation in fish living in polluted waters. In Twardowska I., Allen H.E., HEaggblom M.M., Stefaniak S. (eds) Soil and water pollution monitoring, protection and remediation. NATO Science Series (pp. 69,107-69,114). Dordrecht: Springer.

Jiao, B., Xu, G., Li, D., Luo, J., \& Yang, K. (2012). Hazards of heavy metals in coal. Disaster Advances, 5(4), 1812-1818.

Kaur, T., \& Sinha, A. K. (2019). Pesticides in agricultural run offs affecting water resources: a study of Punjab (India). Agricultural Sciences, 10(10), 1381.

Kosygin, L., Dhamendra, H., \& Gyaneshwari, R. (2007). Pollution status and conservation strategies of Moirang River, Manipur with a note on its aquatic bio-resources. Journal of environmental biology / Academy of Environmental Biology, India, 28, 669-673.

Malik, D. S., Maurya, P., \& Hemant, K. (2015). Alteration in haematological indices of Heteropneustis fossils under stress heavy metals pollution in the Kali river, Uttar Pradesh, India. International Journal of Current Research, 7(5), 1556715567.

Mani, T., Hauk, A., Walter, U., \& Burkhardt-Holm, P. (2015). Microplastics profile along the Rhine River. Scientific Reports, 5, 17988.

Marriott, A. L., Kelly, T. J., Sarkar, S. K., et al. (2020). Elemental composition of aquaculture fish from West Bengal, India: nutrition versus food safety. Environmental Geochemistry and Health, 42, 1211-1228. https://doi.org/10.1007 /s10653-019-00401-8.

Marshall, S., Pettigrove, V., Carew, M., \& Hoffmann, A. (2010). Isolating the impact of sediment toxicity in urban streams. Environmental Pollution, 158(5), 1716-1725.

Martin, J. A. R., Arana, C. D., Ramos-Miras, J. J., Gi, C., \& Boluda, R. (2015). Impact of 70 years urban growth associated with heavy metal pollution. Environmental Pollution, 196, 156-163.

Maurya, P. K., \& Malik, D. S. (2016). Distribution of heavy metals in water, sediments and fish tissue (Heteropneustis fossilis) in Kali River of western U.P. India. International Journal of Fisheries and Aquatic Studies, 4(2), 208-215.

Maurya, P. K., \& Malik, D. S. (2018). Bioaccumulation of heavy metals in tissues of selected fish species from Ganga River, India, and risk assessment for human health. Human and Ecological Risk Assessment: An International Journal, 25(4). https://doi.org/10.1080/10807039.2018.1456897. 
Maurya, P. K., Malika, D. S., Yadavb, K. K., Kumar, A., Kumard, S., \& Kamyab, H. (2019). Bioaccumulation and potential sources of heavy metal contamination in fish species in River Ganga basin: possible human health risks evaluation. Toxicology Reports, 6, 472-481.

Mazumder, G. (2008). Chronic arsenic toxicity \& human health. The Indian Journal of Medical Research, 128(4), 436-447.

Meche, A., Martins, M. C., Lofrano, B. E. S. N., Hardaway, C. J., Merchant, M., \& Verdade, L. (2010). Determination of heavy metals by inductively coupled plasma-optical emission spectrometry in fish from the Piracicaba River in Southern Brazil. Microchemical Journal, 94, 171-174.

Medeiros, R. J., dos Santos, L. M. G., Freire, A. S., Santelli, R. E., Braga, A. M. C., Krauss, T. M., \& Jacob, S. D. C. (2012). Determination of inorganic trace elements in edible marine fish from Rio de Janeiro State, Brazil. Food Control, 23(2), 535-541.

Muller, G. (1969). Index of geoaccumulation in sediments of the Rhine River. Geojournal, 2, 108-118.

Nasr, S. M., Okbah, M. A., \& Kasem, S. M. (2006). Environmental assessment of heavy metal pollution in bottom sediment of Aden Port, Yemen. International Journal of Oceanography, 1(1), 99-109.

Obahiagbon, K., \& Olowojoba, G. (2007). Metal toxicity in mammals, volume 2 of chemical toxicity of metals and metalloids. New York: Plenum press.

Ochieng, E., Lalah, J., \& Wandiga, S. (2007). Analysis of heavy metals in water and surface sediment in five rift valley lakes in Kenya for assessment of recent increase in anthropogenic activities. Bulletin of Environmental Contamination and Toxicology, 79, 570-576. https://doi.org/10.1007/s00128007-9286-4.

Offem, B. O., Akegbejo-Samsons, Y., Omoniyi, I., \& T. (2010). Aspects of ecology of Clarias anguillaris (Teleostei: Clariidae) in the Cross River, Nigeria, Turkish. Journal of Fisheries and Aquatic Sciences, 10, 101-110.

Olatunji-Ojo, A. M., Olayinka-Olagunju, J. O., Odedeyi, D. O., \& Adejuyigbe, A. (2019). Ecological risk assessment of heavy metals in sediment from oil-producing regions of Ilaje Local Government Area of Ondo State, Nigeria. International Journal of Research and Scientific Innovation (IJRSI), 6(6), 263-270.

Olatunji-Ojo, A. M., Alimba, C. G., Adenipekun, C. O., \& Bakare, A. A. (2020). Experimental simulation of somatic and germ cell genotoxicity in male Mus musculus fed extracts of lead contaminated Pleurotus ostreatus (white rot fungi). Environmental Science and Pollution Research. https://doi. org/10.1007/s11356-020-08494-w.

Olawusi-Peters, O. O., Ayo-Olalusi, C. I., \& Adeyemi, T. V. (2015). Bioaccumulation of some trace elements in the gills and tissues of Clarias gariepinus and Oreochromis niloticus in River Ogbese, Ondo River. Journal of Environmental Chemistry and Ecotoxicology, 6(2), 13-19.

Olayinka-Olagunju, J. O., Olatunji-Ojo, A. M., Adejuyigbe, A., Ikuesan, H. A., \& Abubakar, S. E. (2019). Ecological risk assessment of heavy metals in soil of an open dump along old IkareOwo road, Ondo State, Nigeria. Asian Journal of Environment \& Ecology, 9(3), 11.

Olivares-Rieumont, S., la Rosa, D., Lima, L., Graham, D. W., Alessandro, K. D., et al. (2005). Assessment of heavy metal levels in Almendares River sediments - Havana City, Cuba. Water Research, 39 (16, 3945-3953.

Ololade, I. A., \& Ajayi, A. O. (2009). Contamination profile of major rivers along the highways in Ondo State, Nigeria. Journal of Toxicology and Environmental Health Sciences, 1(3), 38-53.

Onjefu, S. A., Abah, J., \& Nambundunga, B. (2017). Some heavy metals' concentrations in roadside dusts at Monte Christo, Windhoek Namibia. International Journal of Environmental Science and Development, 8, 647-652.

Onyari, M. J., Muohi, A. W., Omondi, G., \& Mavuti, K. M. (2003). Heavy metals in sediments from Makupa and PortReitz Creek systems: Kenyan Coast.. Environment International, 28(7), 639-647.

Orjiekwe, C. L., Solola, S. A., \& Chinedu, N. B. (2013). Assessment of water quality of Ogbese River in Ovia North-East Local Government area of Edo State, Nigeria. International Journal of Current Research, 5(11), 34223427.

Oyelami, A. C., Ojo, A. O., Aladejana, J. A., \& Agbede, O. O. (2013). Assessing the effect of a dumpsite on groundwater quality: a case study of Aduramigba estate within Osogbo metropolis. Journal of Environment and Earth Science, 3(1), 120-131.

Prasanna, M. V., Praveena, S. M., \& Chidambaram, S. (2012). Evaluation of water quality pollution indices for heavy metal contamination monitoring: a case study from Curtin Lake, Miri City, East Malaysia. Environment and Earth Science, 67, 1987-2001. https://doi.org/10.1007/s12665-012-1639-6.

Praveena, S. M., Ahmed, A., Radojevic, M., Mohd, H. A., \& Aris, A. Z. (2007). Factor-cluster analysis and enrichment study of mangrove sediments-an example from Mengkabong, Sabah. Malaysian Journal of Analytical Sciences, 11(2), 421-430.

Rabee, A. M., Al-Fatlawy, Y. F., Najim, A.-A.-H., \& Nameer, M. (2011). Using Pollution Load Index (PLI) and geoaccumulation index (I-Geo) for the assessment of heavy metals pollution in Tigris river sediment in Baghdad Region. Journal of Al-Nahrain University, 14(4), 108-114.

Raji, M., Ibrahim, Y., \& Ehinmidu, J. (2010). Physiochemical characteristics and heavy metal levels in drinking water resources in Sokoto Metropolis in North-western Nigeria. Journal of Applied Sciences and Environmental Management, 14, 81-85.

Sánchez-Chardi, A., Peñarroja-Matutano, C., Ribeiro, C. A. O., \& Nadal, J. (2007). Bioaccumulation of metals and effects of a landfill in small mammals. Part II. The wood mouse, Apodemus sylvaticus. Chemosphere, 70(1), 101-109.

Santos, I. R., Friedrich, A. C., \& do Sul, J.A.I. (2009). Marine debris contamination along undeveloped tropical beaches from northeast Brazil. Environmental Monitoring and Assessment, 148(1-4), 455-462.

Sathware, N. G., Paterl, K. G., Vyas, J. B., Patel, S., Trivedi, M. R., Dave, L. M., et al. (2007). Chromium exposure study in chemical based industry. Journal of Environmental Biology, 28, 405-408.

Sharma, R. K., \& Agrawal, M. (2005). Biological effects of heavy metals: an overview. Journal of Environmental Biology, 26(2), 301-313.

Sharma, S., \& Chatterjee, S. (2017). Microplastic pollution, a threat to marine ecosystem and human health: a short review. 
Environmental Science and Pollution Research, 24, 2153021547.

Singh, H., Pandey, R., Singh, S. K., \& Shukla, D. N. (2017). Assessment of heavy metal contamination in the sediment of the River Ghaghara, a major tributary of the River Ganga in Northern India. Applied Water Science, 7(7), 4133-4149.

Singh, J., Yadav, P., Pal, A. K., \& Mishra, V. (2020). Water pollutants: origin and status. In D. Pooja, P. Kumar, P. Singh, \& S. Patil (Eds.), Sensors in water pollutants monitoring: role of material. Advanced Functional Materials and Sensors. Gateway East: Springer. https://doi.org/10.1007 1978-981-15-0671-0_2.

Sobha, V., Varma, N. K., \& Ajith, V. V. (2016). Comparative evaluation of laser etching and acid etching: an in vitro study. International Journal of Laser Dentistry, 6, 6-11. https://doi. org/10.5005/jp-journals-10022-1079.

Solomon, K. R., Baker, D. B., Richards, R. P., Dixon, D. R., Klaine, S. J., \& LaPoint, T. W. (1996). Ecological risk assessment of atrazine in North American surface waters. Environmental Toxicology and Chemistry, 15(1), 31-74.

Tacon, A. G. J., Lemos, D., \& Metian, M. (2020). Fish for health: improved nutritional quality of cultured fish for human consumption. Reviews in Fisheries Science \& Aquaculture. https://doi.org/10.1080/23308249.2020.1762163.

Thinh, N., Ozaki, A. O., Tho, H., Duc, A., Thi, Y., \& Kurosawa, K. (2016). Arsenic and heavy metal contamination in soils under different land use in an estuary in Northern Vietnam. International Journal of Environmental Research and Public Health, 13. https://doi.org/10.3390/ijerph13111091.

Traina, A., Bono, G., Bonsignore, M., Falco, F., Giuga, M., Quinci, E. M., et al. (2019). Heavy metals concentrations in some commercially key species from Sicilian coasts (Mediterranean Sea): potential human health risk estimation. Ecotoxicology and Environmental Safety, 168, 466-478. https://doi.org/10.1016/j.ecoenv.2018.10.056.

Turner, G. F., Seehausen, O., Knight, M. E., Allender, C., \& Robinson, R. L. (2001). How many species of cichlid fishes are there in African lakes? Molecular Ecology, 10(3), 793806.

Vardi, V., \& Chenji, V. (2020). Bioaccumulation of heavy metals in edible marine fish from coastal areas of Nellore, Andhra Pradesh, India. GSC Biological and Pharmaceutical Sciences, 10(01), 18-24.
Venden B. J. P. \& Bernacsek, G.M. (1990). Source book for the inland fishery resources of Africa 2. CIFA Technical Paper 18.2, FAO, Rome, p. 411

WHO (2003) Malathion in drinking water. Background Document for preparation of WHO Guidelines for drinking water Quality. World Health Organization (WHO/SDE/ WSH/ $03.04 / 103)$

WHO (2006): Guidelines for drinking water quality. First Addendum to the third Edition vol. 1. Recommendations pp 491-493

WHO. (2011). Guidelines for drinking water quality. (4th ed.p. 564). Geneva: World Health Organization.

Wogu, D., \& Okaka, E. (2011). Pollution studies on Nigerian rivers: heavy metals in surface water of Warri River, Delta state. Journal of Biodiversity and Environmental Sciences, 1, $7-12$.

Yadav, K. K., Gupta, N., Kumar, V., Khanb, S. A., \& Kumar, A. (2018). A review of emerging adsorbents and current demand for defluoridation of water: Bright future in water sustainability. Environment International, 111, 80-108. https://doi. org/10.1016/j.envint.2017.11.014.

Yi, Y. J., \& Zhang, S. H. (2012). Heavy metal (Cd, Cr, Cu, Hg, Pb, $\mathrm{Zn}$ ) concentrations in seven fish species in relation to fish size and location along the Yangtze River. Environmental Science and Pollution Research, 19(9), 3989-3996.

Yi, Y., Yanga, Z., \& Zhang, S. (2011). Ecological risk assessment of heavy metals in sediment and human health risk assessment of heavy metals in fishes in the middle and lower reaches of the Yangtze River basin. Environmental Pollution, 159, 2575-2585.

Zhao, S., Feng, C., Quan, W., Chen, X., Niu, J., \& Shen, Z. (2012). Role of living environments in the accumulation characteristics of heavy metals in fishes and crabs in the Yangtze River Estuary, China. Marine Pollution Bulletin, 64, 1163-1167.

Zhong, W., Zhang, Y., Wu, Z., Yang, R., Chen, X., Yang, J., et al. (2018). Health risk assessment of heavy metals in freshwater fish in the central and eastern North China. Ecotoxicology and Environmental Safety, 157, 343-349. https://doi. org/10.1016/j.ecoenv.2018.03.048.

Publisher's Note Springer Nature remains neutral with regard to jurisdictional claims in published maps and institutional affiliations. 